\title{
Heat production and body temperature during cooling and rewarming in overweight and lean men
}

Citation for published version (APA):

van Claessens - van Ooijen, A. M., Westerterp, K. R., Wouters, L., Schoffelen, P. F. M., van Steenhoven, A. A., \& van Marken Lichtenbelt, W. D. (2006). Heat production and body temperature during cooling and rewarming in overweight and lean men. Obesity, 14(11), 1914-1920. https://doi.org/10.1038/oby.2006.223

Document status and date:

Published: 01/01/2006

DOI:

10.1038/oby.2006.223

Document Version:

Publisher's PDF, also known as Version of record

Document license:

Taverne

Please check the document version of this publication:

- A submitted manuscript is the version of the article upon submission and before peer-review. There can be important differences between the submitted version and the official published version of record.

People interested in the research are advised to contact the author for the final version of the publication, or visit the DOI to the publisher's website.

- The final author version and the galley proof are versions of the publication after peer review.

- The final published version features the final layout of the paper including the volume, issue and page numbers.

Link to publication

\footnotetext{
General rights Owners
rights.

- You may freely distribute the URL identifying the publication in the public portal. please follow below link for the End User Agreement:

www.umlib.nl/taverne-license

Take down policy

If you believe that this document breaches copyright please contact us at:

repository@maastrichtuniversity.nl

providing details and we will investigate your claim.
}

Copyright and moral rights for the publications made accessible in the public portal are retained by the authors and/or other copyright owners and it is a condition of accessing publications that users recognise and abide by the legal requirements associated with these

- Users may download and print one copy of any publication from the public portal for the purpose of private study or research.

- You may not further distribute the material or use it for any profit-making activity or commercial gain

If the publication is distributed under the terms of Article $25 \mathrm{fa}$ of the Dutch Copyright Act, indicated by the "Taverne" license above, 


\title{
Human Physiology
}

\section{Heat Production and Body Temperature During Cooling and Rewarming in Overweight and Lean Men}

\author{
Anne M.J. Claessens-van Ooijen, * Klaas R. Westerterp, * Loek Wouters, * Paul F.M. Schoffelen, * \\ Anton A. van Steenhoven, $\dagger$ and Wouter D. van Marken Lichtenbelt*
}

\begin{abstract}
CLAESSENS-VAN OOIJEN, ANNE M.J., KLAAS R. WESTERTERP, LOEK WOUTERS, PAUL F.M. SCHOFFELEN, ANTON A. VAN STEENHOVEN, AND WOUTER D. VAN MARKEN LICHTENBELT. Heat production and body temperature during cooling and rewarming in overweight and lean men. Obesity. 2006;14: 1914-1920.
\end{abstract}

Objective: To compare overweight and lean subjects with respect to thermogenesis and physiological insulation in response to mild cold and rewarming.

Research Methods and Procedures: Ten overweight men (mean BMI, $29.2 \pm 2.8 \mathrm{~kg} / \mathrm{m}^{2}$ ) and 10 lean men (mean BMI, $21.1 \pm 2.0 \mathrm{~kg} / \mathrm{m}^{2}$ ) were exposed to cold air for 1 hour, followed by 1 hour of rewarming. Body composition was determined by hydrodensitometry and deuterium dilution. Heat production and body temperatures were measured continuously by indirect calorimetry and thermistors, respectively. Muscle activity was recorded using electromyography.

Results: In both groups, heat production increased significantly during cooling (lean, $p=0.004$; overweight, $p=$ 0.006). The increase was larger in the lean group compared with the overweight group ( $p=0.04$ ). During rewarming, heat production returned to baseline in the overweight group and stayed higher compared with baseline in the lean group $(p=0.003)$. The difference in heat production between

Received for review July 13, 2005.

Accepted in final form August 2, 2006.

The costs of publication of this article were defrayed, in part, by the payment of page charges. This article must, therefore, be hereby marked "advertisement" in accordance with 18 U.S.C. Section 1734 solely to indicate this fact.

*Department of Human Biology, NUTRIM (Nutrition and Toxicology Research Institute Maastricht), Maastricht University, Maastricht, The Netherlands, and †Department of Energy Technology, University of Technology, Eindhoven, The Netherlands.

Address correspondence to Anne M.J. Claessens-van Ooijen, Department of Human Biology, Maastricht University, Universiteitssingel 50, P.O. Box 616, 6200 MD Maastricht, The Netherlands.

E-mail: m.vanooijen@HB.unimaas.nl

Copyright () 2006 NAASO rewarming and baseline was larger in the lean $(p=0.01)$ than in the overweight subjects. Weighted body temperature of both groups decreased during cold exposure (lean, $p=$ 0.002 ; overweight, $p<0.001$ ) and did not return to baseline during rewarming.

Discussion: Overweight subjects showed a blunted mild cold-induced thermogenesis. The insulative cold response was not different among the groups. The energy-efficient response of the overweight subjects can have consequences for energy balance in the long term. The results support the concept of a dynamic heat regulation model instead of temperature regulation around a fixed set point.

Key words: cold, energy balance, individual variation, body composition, temperature distribution

\section{Introduction}

Adaptive thermogenesis, the dissipation of energy in the form of heat in response to diet or cold, has been implicated in the regulation of energy balance and body temperature. Most studies focus on diet-induced thermogenesis. However, cold-induced thermogenesis is also of interest with respect to weight regulation, because it is highly variable among individuals. Humans can respond to cold by increasing metabolism, decreasing peripheral body temperature (insulation), or hypothermia. Under mild cold conditions, hypothermia is unlikely to occur. Under severe cold conditions, it has been shown that individuals differ in the relative contributions of the metabolic and insulative response (1). Under mild cold conditions, such inter-individual variation has also been reported in a 24-hour cold exposure (2). The observed increase in 24-hour energy expenditure varied from 0.15 to $1.45 \mathrm{MJ} / \mathrm{d}$. During a short-term study (3-hour mild cold exposure), we also found a large variation (3), ranging from $-4 \%$ to $+30 \%$ in winter (4). Interestingly, by repeating the experiment in another season, we were able to show that the relative contribution of metabolic and insulative response was subject-specific (4). 
We posed the question whether overweight people can be characterized by an "overweight"-specific cold response. Differences between overweight and lean people might be attributable to the insulation properties of body fat (5-8), surface-to-volume ratio (9), or skin vasoconstrictive reaction to cold (10). These three properties are involved in reducing body heat loss from the skin. Lean and obese persons can also differ in cold-induced thermogenesis, possibly through differences in autonomic responsiveness $(11,12)$.

Indeed, some studies indicate reduced cold-induced thermogenesis, a high level of insulation in obesity under severe cold conditions $(1,13)$, and decreased autonomic responsiveness $(11,12)$. However, with respect to moderate temperature differences, few studies on obesity have been performed. Therefore, we investigated whether lean and overweight subjects differ in cold-induced thermogenesis under mild cold conditions. We focused on mild cold, because small changes in ambient temperature occur in daily life in most modern societies in temperate zones. We seldom shiver nowadays, but during wintertime, people do experience cold when leaving a comfortable, warm room, walking to a car, waiting for public transportation, etc. Mild cold exposure is a common daily occurrence.

We tested the hypothesis that during a short-term mild cold exposure of 1 hour and rewarming, overweight subjects show a blunted thermogenic response and an increased insulative response compared with their lean counterparts.

\section{Research Methods and Procedures \\ Subjects}

Two groups of 10 healthy, non-smoking male volunteers were recruited: a lean group with a mean BMI of $21.1 \pm 2.0$ $\mathrm{kg} / \mathrm{m}^{2}$ (range, 17.9 to $23.4 \mathrm{~kg} / \mathrm{m}^{2}$ ) and an overweight group with a mean BMI of $29.2 \pm 2.8 \mathrm{~kg} / \mathrm{m}^{2}$ (range, 24.7 to $33.2 \mathrm{~kg} / \mathrm{m}^{2}$ ). The present study was approved by the Ethics Committee of Maastricht University. Detailed information concerning purpose and methods used in the study was given before written consent was obtained. Subject characteristics are presented in Table 1.

\section{Design}

The experiment consisted of a cold air exposure test followed by rewarming. Subjects lay on a chair, with their legs supported, in $15^{\circ} \mathrm{C}$ air and were covered with a duvet $\left(375 \mathrm{~g} / \mathrm{m}^{2}\right)$. This was the thermoneutral condition. The duvet was removed after 60 minutes of baseline measurement. The cold exposure started the moment the duvet was removed. After 60 minutes of cold exposure, the duvet was replaced, and this was the start of the rewarming phase. The test was terminated after 60 minutes of rewarming. The subjects were wearing standard clothing with an insulative value of 0.71 clo $\left(\mathrm{Icl}=0.109 \mathrm{~m}^{2} \times{ }^{\circ} \mathrm{C} / \mathrm{W}\right)$, consisting of
Table 1. Subject characteristics

\begin{tabular}{lccc}
\hline & $\begin{array}{c}\text { Total group } \\
(\boldsymbol{n}=\mathbf{2 0})\end{array}$ & $\begin{array}{c}\text { Lean } \\
(\boldsymbol{n}=\mathbf{1 0})\end{array}$ & $\begin{array}{c}\text { Overweight } \\
(\boldsymbol{n}=\mathbf{1 0})\end{array}$ \\
\hline Age (years) & $25 \pm 6$ & $23 \pm 4$ & $27 \pm 7$ \\
Height $(\mathrm{m})$ & $1.81 \pm 0.07$ & $1.82 \pm 0.08$ & $1.80 \pm 0.06$ \\
Weight* $(\mathrm{kg})$ & $82.1 \pm 14.5$ & $69.7 \pm 7.1$ & $94.5 \pm 6.8$ \\
BMI* $^{*}\left(\mathrm{~kg} / \mathrm{m}^{2}\right)$ & $25.2 \pm 4.8$ & $21.1 \pm 2.0$ & $29.2 \pm 2.8$ \\
FM* $\left.^{2} \%\right)$ & $20.6 \pm 7.2$ & $14.9 \pm 4.2$ & $27.0 \pm 5.3$ \\
FFM $^{*}(\mathrm{~kg})$ & $64.4 \pm 7.7$ & $58.8 \pm 5.0$ & $70.0 \pm 5.5$
\end{tabular}

Values are averages \pm standard deviation. FM, fat mass; FFM, fat-free mass.

* Lean vs. overweight, $p<0.05$.

sweatpants ( 0.28 clo), a sweater ( 0.37 clo), socks that covered only the feet ( 0.02 clo), and briefs ( 0.04 clo). The face, hands, and ankles were exposed directly to the environment. Heat production and body temperatures were measured continuously.

Subjects arrived at the laboratory by car or public transportation after overnight fasting to avoid any effects of activity or diet. They were instructed not to perform any strenuous activities the day before the experiment.

Body composition was determined on a separate visit within 1 week of the experiment.

\section{Measurements and Instrumentation}

Body composition was calculated according to Siri's three-compartment model (14). For this calculation, body density and total body water were determined using underwater weighing and deuterium dilution (15). The latter was determined according to the Maastricht protocol (16).

Oxygen consumption and carbon dioxide production were measured with an automated respiratory gas analyzer using a ventilated hood system (Omnical; IDEE, Maastricht, The Netherlands). Gas analyzers were calibrated before the experiments. Heat production was calculated from these data according to Weir's method (17).

Rectal temperature was measured continuously by a thermistor probe (YSI probes, series 402; Yellow Springs Instrument Co., Yellow Springs, $\mathrm{OH}$ ) inserted $10 \mathrm{~cm}$ beyond the anal sphincter.

Skin temperatures were measured by surface thermistors (YSI probes, series 409B; Yellow Springs Instrument Co.) placed on the dorsal side of the hand, forearm, upper arm, chest, abdomen, lower back, anterior thigh, posterior calf, and dorsal side of the foot. Temperatures were registered and recorded at 1-minute intervals (Tiretherm; IDEE).

Mean skin temperature was calculated according to Ramanathan's method (18). Weighted body temperature 
Table 2. Heat production and body temperatures at baseline, during cooling, and during re-warming

\begin{tabular}{|c|c|c|c|}
\hline Temperature and group & Baseline & Cooling & Rewarming \\
\hline \multicolumn{4}{|l|}{ Heat production $\left(\mathrm{W} / \mathrm{m}^{2}\right)$} \\
\hline Lean & $44.7 \pm 3.1$ & $53.4 \pm 7.2^{*}$ & $50.0 \pm 4.2 *$ \\
\hline Overweight & $44.7 \pm 3.9$ & $47.5 \pm 4.5^{*}$ & $45.9 \pm 4.7$ \\
\hline \multicolumn{4}{|l|}{ Rectal temperature $\left({ }^{\circ} \mathrm{C}\right)$} \\
\hline Lean & $36.8 \pm 0.2$ & $36.9 \pm 0.2$ & $36.8 \pm 0.2$ \\
\hline Overweight & $36.9 \pm 0.2$ & $36.9 \pm 0.2$ & $36.9 \pm 0.2$ \\
\hline \multicolumn{4}{|l|}{ Mean skin temperature $\left({ }^{\circ} \mathrm{C}\right)$} \\
\hline Lean & $32.4 \pm 0.4$ & $29.6 \pm 0.8^{*}$ & $30.5 \pm 0.6^{*}$ \\
\hline Overweight & $32.6 \pm 0.6$ & $29.9 \pm 0.7^{*}$ & $30.6 \pm 0.7^{*}$ \\
\hline \multicolumn{4}{|l|}{ Trunk skin temperature $\left({ }^{\circ} \mathrm{C}\right)$} \\
\hline Lean & $34.6 \pm 0.2 \dagger$ & $32.7 \pm 0.4 * \dagger$ & $34.3 \pm 0.3 * \dagger$ \\
\hline Overweight & $33.9 \pm 0.8$ & $32.0 \pm 0.6^{*}$ & $33.5 \pm 0.8$ \\
\hline \multicolumn{4}{|l|}{ Distal skin temperature $\left({ }^{\circ} \mathrm{C}\right)$} \\
\hline Lean & $30.5 \pm 0.8$ & $26.6 \pm 1.2^{*}$ & $27.0 \pm 1.1^{*}$ \\
\hline Overweight & $31.5 \pm 1.3$ & $28.0 \pm 1.9^{*}$ & $28.2 \pm 1.9^{*}$ \\
\hline \multicolumn{4}{|l|}{ Weighted temperature $\ddagger\left({ }^{\circ} \mathrm{C}\right)$} \\
\hline Lean & $36.8 \pm 0.2$ & $36.5 \pm 0.2 *$ & $36.5 \pm 0.3^{*}$ \\
\hline Overweight & $36.9 \pm 0.2$ & $36.6 \pm 0.2 *$ & $36.6 \pm 0.3^{*}$ \\
\hline \multicolumn{4}{|c|}{$\begin{array}{l}\text { Values are averages } \pm \text { standard deviation. } \\
* p<0.05 \text { vs. baseline. } \\
\dagger p<0.05 \text { overweight vs. lean. } \\
¥ \text { Weighted temperature }=\text { weighted average of rectal and mean skin temperature. }\end{array}$} \\
\hline
\end{tabular}

$(\text { WBT })^{1}$ was calculated as a measure of rectal and mean skin temperatures according to Cunningham et al. (19). This value provides an estimate of total body temperature as a possible drive for heat production. To study temperature distribution, trunk and distal skin temperatures were calculated. Trunk temperature was calculated as the average of skin temperatures measured at the lower back, the abdomen, and the chest. Distal skin temperature was calculated as the average of skin temperatures measured at the hand and foot.

Possible shivering was detected using electromyography (Tiretherm). Electromyographic electrodes were placed 3 $\mathrm{cm}$ apart on the skin at the musculus pectoralis major, as described previously $(4,20,21)$. This site was chosen because, in people having a normal amount of fat, shivering starts in the upper trunk region and propagates toward the extremities (21).

Baseline values were calculated over Minutes 21 to 50 of the first hour. During cold exposure and rewarming, Minutes 11 to 60 were used for calculations to avoid the influence of removing or replacing the duvet.

${ }^{1}$ Nonstandard abbreviation: WBT, weighted body temperature.

\section{Statistical Analysis}

Data are reported as means \pm standard deviation. Results were considered statistically significant at the $p<0.05$ level. The SPSS software program (version 11.5.0; SPSS, Inc., Chicago, IL) was used for statistical analyses.

Between-group differences were tested by unpaired $t$ tests. Within-group changes were tested by paired $t$ tests. Linear regression analysis was used to study the relation between skin temperatures and fat percentage.

\section{Results}

At baseline, there were no significant differences between lean and overweight subjects in energy expenditure (expressed in $\mathrm{W} / \mathrm{m}^{2}$ ) and most temperatures (Table 2). Only trunk temperature was lower in the overweight men $(p=$ $0.02)$.

Heat production increased significantly during the hour of cold exposure in both groups $(p=0.004$ and $p=0.006$ for lean and overweight subjects, respectively) (Table 2; Figure 1). During rewarming, heat production decreased in both groups and returned to baseline in the overweight group. In the lean group, heat production during rewarming 


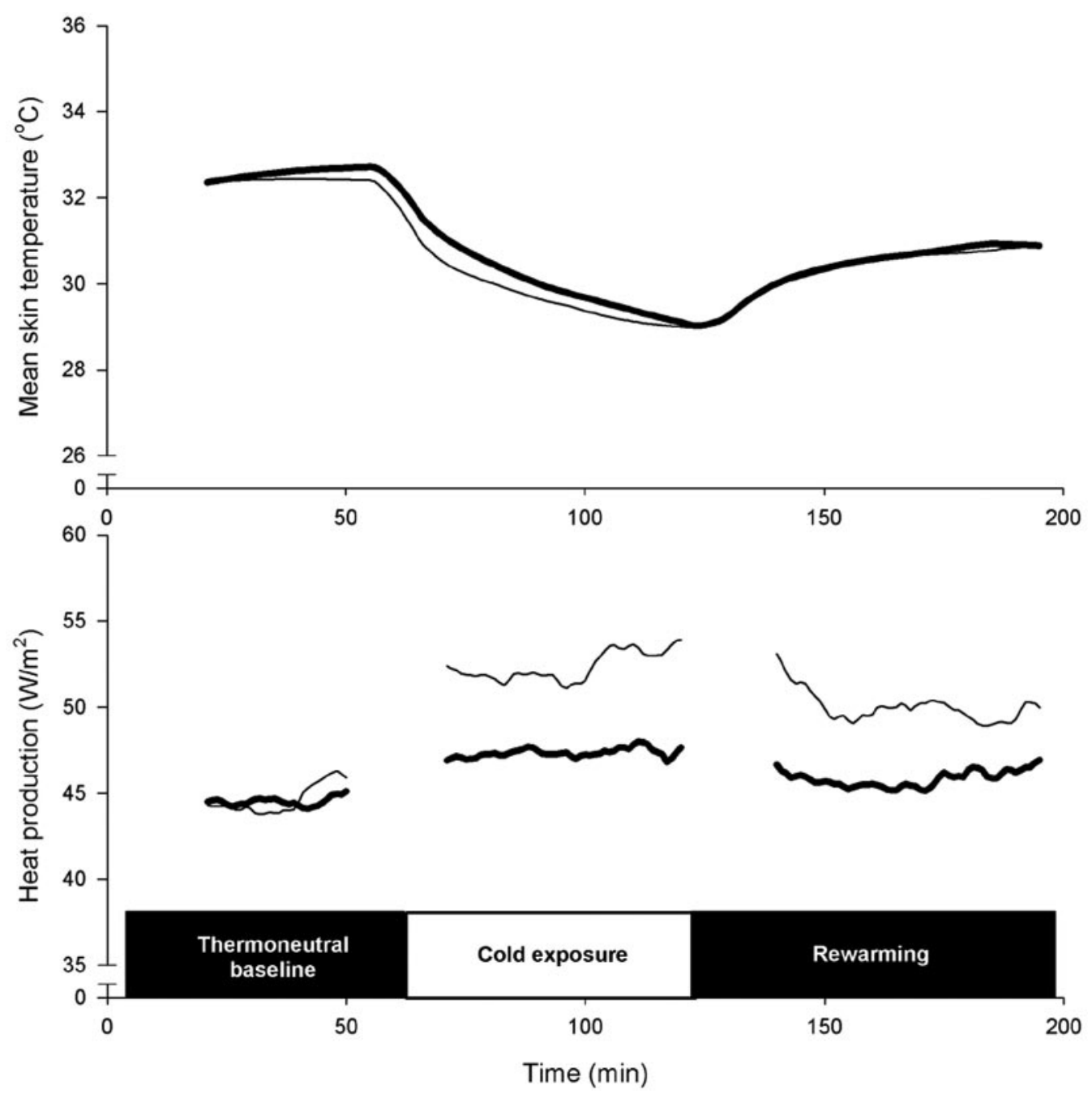

Figure 1: Course of mean heat production $\left(\mathrm{W} / \mathrm{m}^{2}\right)$ and mean skin temperature $\left({ }^{\circ} \mathrm{C}\right)$ in overweight (thick line) and lean (thin line) subjects.

remained significantly higher compared with baseline $(p=$ 0.003 ) (Table 2). Shivering did not occur during any stage of the experiment.

At baseline, during cooling, and during rewarming, heat production was not significantly different between the groups (Table 2). However, the increase in heat production during cooling was significantly larger in the lean group compared with the overweight group $(p=0.04)$. The difference in heat production between rewarming and baseline was also significantly greater in the lean group compared with the overweight group ( $p=0.01$ ).

Rectal temperature was not significantly different between groups at any stage of the experiment and did not change significantly compared with baseline (Table 2).

Trunk temperature was significantly lower in the overweight group compared with the lean group during the three stages of the test ( $p=0.02, p=0.007$, and $p=0.006$, respectively) (Table 2 ). Within groups, trunk temperature decreased significantly during cold exposure $(p<0.001$ in both groups). During rewarming, trunk temperature was not significantly different from baseline in the overweight group, but it stayed significantly lower compared with baseline in the lean group ( $p=0.03$ ) (Table 2).

Mean skin temperature decreased significantly during cold exposure $(p<0.001)$ in both groups. During rewarming, mean skin temperature did not return to baseline in the two groups ( $p<0.001$ compared with baseline).

WBT decreased significantly during cold exposure ( $p=$ 0.002 and $p<0.001$ for lean and overweight subjects, respectively) in both groups. During rewarming, WBT increased but did not return to baseline $(p=0.01$ and $p=$ 0.003 compared with baseline in the lean and overweight groups, respectively).

Distal skin temperature decreased significantly during cold exposure $(p<0.001)$ and increased during rewarming. Distal skin temperature did not return to baseline values in both groups $(p<0.001$ for both groups compared with baseline). 

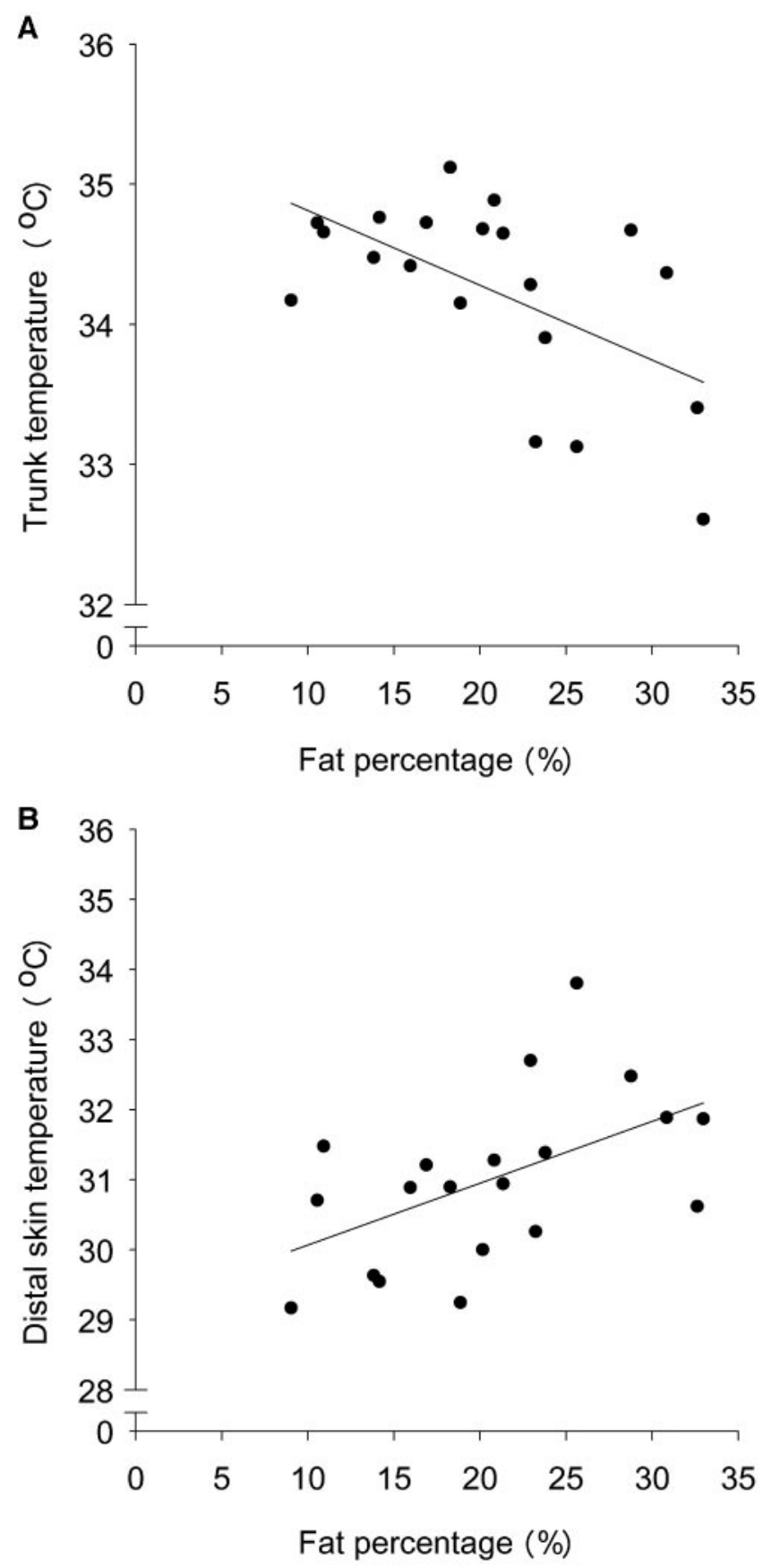

Figure 2: (A) Trunk skin temperature $\left({ }^{\circ} \mathrm{C}\right)$ vs. fat percentage $(\%)$ at baseline. $Y=-0.053 X+35.35\left(r^{2}=0.32, p=0.01\right)$. (B) Distal skin temperature $\left({ }^{\circ} \mathrm{C}\right)$ vs. fat percentage $(\%)$ at baseline. $Y=$ $0.088 X+29.19\left(r^{2}=0.28, p=0.02\right)$

Trunk temperature was negatively related to fat percentage at baseline $\left(r^{2}=0.32, p=0.009\right)$ (Figure 2A). A similar relationship was evident during cold exposure and rewarming $\left(r^{2}=0.40, p=0.003 ; r^{2}=0.36, p=0.005\right.$, respectively).
Distal skin temperature was positively related to fat percentage at baseline $\left(r^{2}=0.28, p=0.02\right)$ and during cold exposure and rewarming $\left(r^{2}=0.25, p=0.03 ; r^{2}=0.29\right.$, $p=0.01$, respectively) (Figure 2B).

\section{Discussion}

This study tested whether overweight subjects, relative to their lean counterparts, show a low (i.e., mild) cold-induced thermogenesis and a high insulative cold response. Heat production corrected for body surface area indeed increased significantly less in the overweight subjects compared with lean subjects during 1 hour of mild cold exposure. Moreover, energy expenditure of the overweight subjects returned to baseline during the period of rewarming, whereas energy expenditure in the lean subjects remained elevated during that hour. Cold-induced changes in core-skin temperature gradients were not significantly different between lean and overweight subjects. Therefore, this study demonstrated that overweight subjects showed a blunted coldinduced thermogenesis, but there was no difference in the insulative cold response between lean and overweight subjects.

The extra heat production in lean relative to overweight subjects must have been dissipated and should be reflected in an elevated skin temperature. Most likely, during cold exposure, vasoconstriction of the extremities occurred in both groups. Indeed, there were no differences in distal temperatures between the groups. One would expect increased skin temperatures at other skin sites, but there were not differences between lean and overweight subjects at the measured sites. Only mean trunk temperature was significantly higher in the lean subjects, but this occurred during all stages of the experiment, including baseline. It is possible that temperature distribution changes differ between the groups (22). The results indicate that the overweight subjects preserved heat more efficiently through a smaller heat loss compared with body size.

On average, heat production increased by $11.8 \%$ during cold exposure. For the lean group, the average increase was $17.2 \%$, and for the overweight group, the increase was $6.4 \%$. The increase in heat production during cold exposure was three times as large in lean subjects as compared with overweight subjects. Because heat production during rewarming was relatively high only in the lean group, the total effect of temporary cold exposure is even larger. This has consequences for energy balance (23). We do not know whether this energy-efficient response of the overweight subjects plays a role in the development of overweight, but it has consequences for long-term energy balance and weight maintenance. 
We calculated WBT values to evaluate whether temperature or heat was regulated during cold exposure. WBT can be used as a possible drive for heat production (19). During cold exposure, WBT decreased in both groups, and during rewarming, it increased. However, in both groups, the WBT during rewarming remained low compared with baseline. Apparently, 1 hour of rewarming was not sufficient to return WBT to baseline. On the other hand, in both groups, heat production decreased during rewarming. In the overweight group, mean heat production even returned to the baseline level. This suggests that heat production is not regulated exclusively by body temperature, but most likely heat loss is involved.

The concept of heat regulation, as opposed to the classic concept of temperature regulation, has been suggested by Glaser and Newling (24) and Webb (23,25). Webb (23) showed that heat balance occurs at many levels of activity. These activities range from sleep to intense sustained exercise, and at every level of heat balance, there is a resultant body temperature that is directly proportional to heat production (25). In addition, body heat content returns to the same starting point every day and after exercise (25).

This was recently confirmed by Tikuisis (26), who found that heat balance precedes the stabilization of body temperature during cold water immersion. At the moment that heat debt reversed and started to decrease, heat production remained at the same level, while core temperature was still decreasing (26). In the present experiment, heat production was already decreasing while body temperature was still below baseline values. These observations support the concept of a dynamic model of heat regulation instead of temperature regulation around a fixed set point.

The only significant difference between groups in body temperature was found in trunk temperature. Trunk temperature was significantly lower in the overweight group during all stages of the experiment. The negative relation of trunk temperature to fat percentage $\left(r^{2}=0.32, p=0.009\right)$ suggests that local fat might be involved. A thicker layer of fat might be responsible for reduced heat transfer to the skin (27). The positive relation between distal skin temperatures and body fat percentage underlines the relative importance of distal body sites for heat dissipation in overweight subjects.

In conclusion, overweight subjects showed a blunted cold-induced thermogenesis. The study did not show a difference in insulative cold response between lean and overweight subjects. The increase in heat production in response to a mild cold stimulus was three times as large in lean subjects compared with overweight subjects. Because, during rewarming, heat production was increased in the lean subjects, the total effect of temporary cold exposure is even larger. Our observations support the concept of a dynamic model of heat regulation instead of temperature regulation around a fixed set point. Because we chose mild cold conditions, as encountered in everyday life, it is likely that the observed blunted cold-induced thermogenesis in the overweight will have consequences for energy balance and weight maintenance in the long term.

\section{Acknowledgment}

A. M. J. Claessens-van Ooijen was appointed by Biomedical Technology, Technical University Eindhoven. The study was carried out at Human Biology, Maastricht University.

\section{References}

1. Bittel JH. Heat debt as an index for cold adaptation in men. J Appl Physiol. 1987;62:1627-34.

2. van Marken Lichtenbelt WD, Schrauwen P, van De Kerckhove S, Westerterp-Plantenga MS. Individual variation in body temperature and energy expenditure in response to mild cold. Am J Physiol Endocrinol Metab. 2002;282:E1077-83.

3. van Ooijen AMJ, van Marken Lichtenbelt WD, Westerterp KR. Individual differences in body temperature and the relation to energy expenditure: the influence of mild cold. J Therm Biol. 2001;26:455-9.

4. Van Ooijen AM, Van Marken Lichtenbelt WD, Van Steenhoven AA, Westerterp KR. Seasonal changes in metabolic and temperature responses to cold air in humans. Physiol Behav. 2004;82:545-53.

5. Otte JW, Merrick MA, Ingersoll CD, Cordova ML. Subcutaneous adipose tissue thickness alters cooling time during cryotherapy. Arch Phys Med Rehabil. 2002;83:1501-5.

6. Anderson GS, Martin AD. Calculated thermal conductivities and heat flux in man. Undersea Hyperb Med. 1994;21:43141.

7. Bar-Or O, Lundegren HM, Buskirk ER. Heat tolerance of exercising obese and lean women. J Appl Physiol. 1969;26: 403-9.

8. Haymes EM, McCormick RJ, Buskirk ER. Heat tolerance of exercising lean and obese prepubertal boys. J Appl Physiol. 1975;39:457-61.

9. Kurz A, Sessler DI, Christensen R, Dechert M. Heat balance and distribution during the core-temperature plateau in anesthetized humans. Anesthesiology. 1995;83:491-9.

10. Valensi P, Smagghue O, Paries J, Velayoudon P, Lormeau B, Attali JR. Impairment of skin vasoconstrictive response to sympathetic activation in obese patients: influence of rheological disorders. Metabolism. 2000;49:600-6.

11. Matsumoto T, Miyawaki C, Ue H, Kanda T, Yoshitake Y, Moritani T. Comparison of thermogenic sympathetic response to food intake between obese and non-obese young women. Obes Res. 2001;9:78-85.

12. Matsumoto T, Miyawaki T, Ue H, Kanda T, Zenji C, Moritani T. Autonomic responsiveness to acute cold exposure in obese and non-obese young women. Int J Obes Relat Metab Disord. 1999;23:793-800. 
13. Contaldo F, Scalfi L, Coltordi A, Lanzilli A. Reduced cold-induced thermogenesis in familial human obesity. Klin Wochenschr. 1986;64:177-80.

14. Siri WE. Body composition from fluids and density: analysis of methods. In: Brozek J, Henschel A, eds. Techniques for Measuring Body Composition. Washington DC: National Academy of Sciences; 1961, pp. 223-44.

15. Ellis KJ. Human body composition: in vivo methods. Physiol Rev. 2000;80:649-80.

16. Westerterp KR, Wouters L, van Marken Lichtenbelt WD. The Maastricht protocol for the measurement of body composition and energy expenditure with labeled water. Obes Res. 1995;3(Suppl 1): 49-57.

17. Weir JB. New methods for calculating metabolic rate with special reference to protein metabolism: 1949. Nutrition. 1990;6:213-21.

18. Ramanathan NL. A new weighting system for mean surface temperature of the human body. J Appl Physiol. 1964;19: 531-3.

19. Cunningham DJ, Stolwijk JA, Wenger CB. Comparative thermoregulatory responses of resting men and women. $J$ Appl Physiol. 1978;45:908-15.
20. Bell DG, Tikuisis P, Jacobs I. Relative intensity of muscular contraction during shivering. J Appl Physiol. 1992;72: 2336-42.

21. Tikuisis P, Bell DG, Jacobs I. Shivering onset, metabolic response, and convective heat transfer during cold air exposure. J Appl Physiol. 1991;70:1996-2002.

22. Webb P. Temperatures of skin, subcutaneous tissue, muscle and core in resting men in cold, comfortable and hot conditions. Eur J Appl Physiol. 1992;64:471-6.

23. Webb P. The physiology of heat regulation. Am J Physiol. 1995;268:R838-50.

24. Glaser EM, Newling PS. The control of body temperature in thermal balance. J Physiol. 1957;137:1-11.

25. Webb P. Daily activity and body temperature. Eur J Appl Physiol Occup Physiol. 1993;66:174-7.

26. Tikuisis P. Heat balance precedes stabilization of body temperatures during cold water immersion. J Appl Physiol. 2003; 95:89-96.

27. Kasai T, Hirose M, Matsukawa T, Takamata A, Tanaka Y. The vasoconstriction threshold is increased in obese patients during general anaesthesia. Acta Anaesthesiol Scand. 2003;47: 588-92. 